\title{
CAPE MAY WARBLER IN MANITOBA IN DECEMBER
}

PETER TAYLOR, P.O. Box 597, Pinawa, Manitoba. ROE 1 L0

On 11 December 1987 Doreen Dick reported an unusual bird that had been visiting her feeder at Seven Sisters, Manitoba for about 2 weeks. Her detailed description suggested Cape May Warbler and this was confirmed on 12 December when the bird was watched for a few minutes from about $20 \mathrm{~m}$, using $7 x$ binoculars. Time constraints did not permit closer observation and the bird could not be located the following day, nor was it seen again.

Identification was based on the following field marks. The breast and belly were a fairly bright golden yellow, but the under-tail coverts were whitish. The yellow extended up from the breast to a patch behind the cheeks; there was a slight rusty tinge in the cheeks themselves. The entire breast was strongly streaked with dusky, extending into long stripes on the flanks. The upper parts were mainly greenish brown; the only strongly contrasting marking was a diffuse yellow-green patch on the rump, visible when the bird hovered near the feeder. The wing bars were indistinct. Doreen Dick also noted that the bill and legs were dark, and there were a few white spots in the tail.

This description differs in detail from all illustrations in the commonly used field guides; the combination of fairly bright yellow breast and indistinct wing-bars suggests an immature male in transitional plumage. All other warblers with yellow rump and streaked breast (Magnolia, Palm and Yellow-rumped) are eliminated by the other details.

This appears to be the first December record of a warbler in Manitoba. Any warbler other than the Yellow-rumped is a rare sight after mid-October, and even that comparatively hardy species is not often seen in November. The following records, however, reveal a pattern of individual Cape Mays lingering until late fall, and visiting feeders.

A dingy-plumaged immature visited Bea and Bill Mathers' feeder in Pinawa from late October to 12 November 1980 (see photograph). ${ }^{6}$ Another was seen at Victoria Beach on 1 November 1986 by a large party of birders including G.D. Grieef, R.W. Knapton, R.F. Koes, R. Parsons, M. Siepman and R. Tkachuk (pers. comm.). ${ }^{2}$ Both these birds fed on suet. Not quite so late in the year, Warren Johnston and Gordon Smith saw a Cape May eating suet at a Seven Sisters feeder on 19 October 1963; it was not seen the following day. ${ }^{3}$ Rudolf Koes saw an immature feeding on a cankerworm moth in East Kildonan, Winnipeg, on 24 October 1983 (pers. comm.).

The survival of such a delicate bird as a warbler until mid-December 1987 resulted from an unusually mild and snowfree period in November and early December. The bird disappeared after the first lasting snowfall of the winter, which came on 10-12 December. During its visits to the feeder it seemed to be in good condition. Dick saw it drive away Blackcapped Chickadees and White-breasted Nuthatches, not just from the feeder but right out of the tree. It was active when seen by the author, but it probably succumbed to the cold that night. When Dick first saw the warbler, it was feeding on suet attached to a tree, but it later took crumbs and sunflower-seed debris from a more sheltered bird-table. 


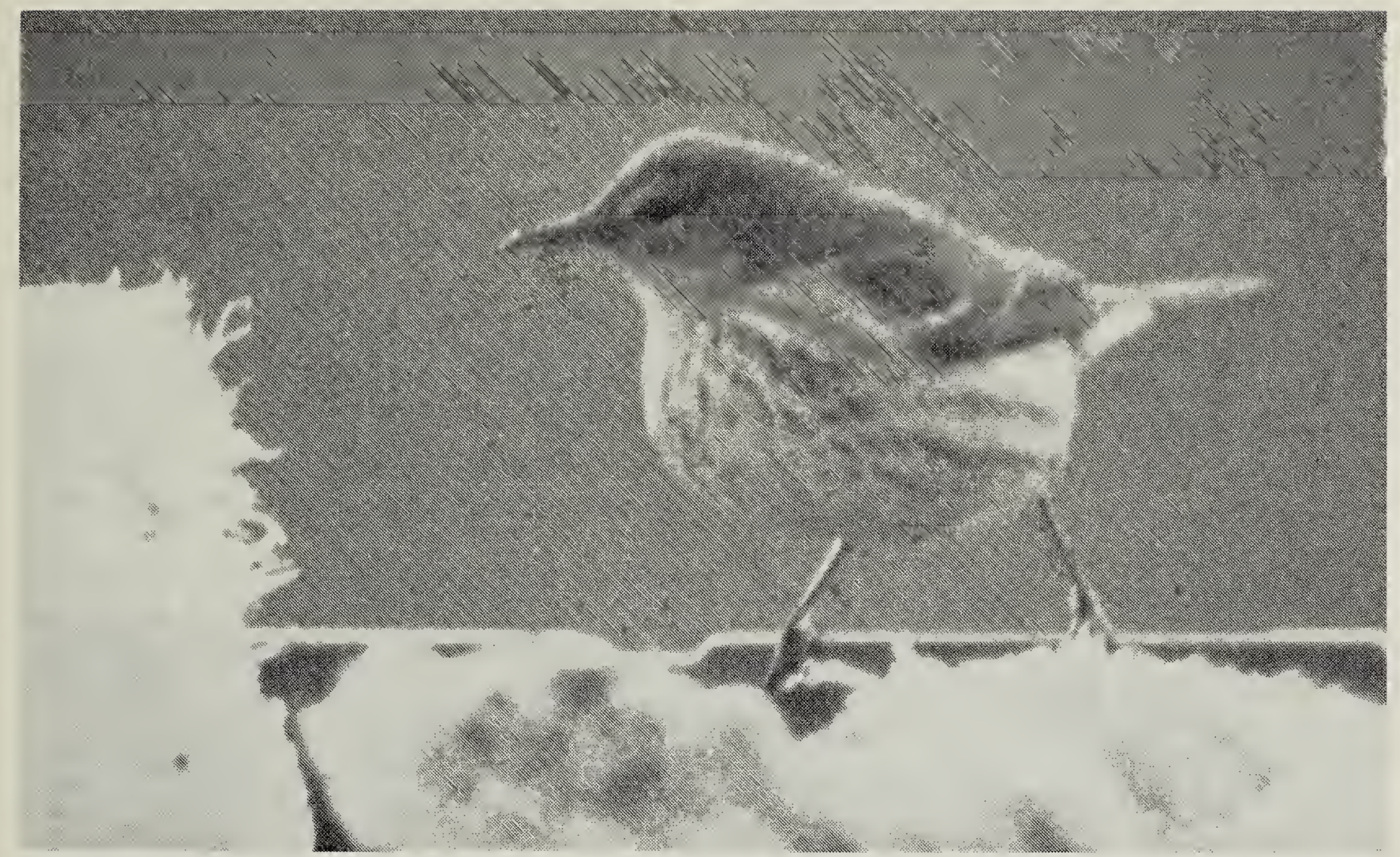

Cape May Warbler feeding on suet in Pinawa, Manitoba, 2 November $1980 \quad$ P. Taylor

The main winter range of the Cape May Warbler is in the West Indies and southern Florida. ${ }^{1}$ It has been recorded casually in winter in southern California, southern Arizona, and the central and eastern United States. ${ }^{1}$ A survey of seasonal reports in American Birds since 1977 shows that the Manitoba records constitute the northwestern extreme of a broad pattern of lingering Cape Mays. Individuals have stayed until December as far north as Minnesota and Ontario (Table 1). Many of these birds were regular feeder visitors, with suet often the food of choice. Reports of successful overwintering (at least to the end of February) extend north to Illinois, Indiana, Pennsylvania and West Virginia (Table 1). ${ }^{4} \mathrm{~A}$ wintering

\section{Table 1. LATE OR OVERWINTERING CAPE MAY WARBLERS IN CANADA AND THE NORTHERN UNITED STATES*}

State or Province

Minnesota

Wisconsin

Michigan

Indiana

Illinois

Pennsylvania

Ontario

Nova Scotia

\section{Last Date}

27 December 1982

23 December 1984

7 January 1980

27 February 1980

2 March 1983

29 February 1980

4 December 1982

13 December 1983
Reference - American Birds

1983, 37(3):305

$1985,39(2): 170$

$1980,34(3): 276$

$1980,34(3): 279$

$1983,37(3): 308$

$1980,34(3): 273$

$1983,37(3): 298$

$1984,38(3): 295$

* Not a comprehensive compilation 
bird at Denver, Colorado in 1985-1986 attracted a lot of attention from the news media. $^{5}$

It is curious that this species of warbler shows such a propensity for using suet feeders when lingering north of its usual winter range. Only a few other warblers (Orange-crowned, Pine, Tennessee, Townsend's, Yellow-rumped and Yellowthroated) are indicated by Terres to be regular feeder users. ${ }^{7}$ Of these six species, all but the Tennessee winter in fair numbers in mild regions of the United States so their use of feeders is not unexpected.

Thanks go to R. F. Koes for information on the 1963, 1983 and 1986 sightings and for helpful comments on the manuscript.

1 AMERICAN ORNITHOLOGISTS' UNION 1983. Check-list of North American birds.
Sixth. ed. pp. 609-610.

2 HARRIS, W.C. 1987. The autumn Migration: Prairie Provinces region. Am. Birds 41:105.

${ }^{3}$ HOSFORD, H. 1963. Wild wings, Winnipeg Tribune. 28 October 1963.

${ }^{4}$ HURLEY, G. and T. HURLEY 1982. Wintering Cape May Warbler [in West Virginia]. Redstart 49:98.

5 KINGERY, H.E. 1986. The winter season: mountain west region. Am. Birds 40:309.

6 TAYLOR, P. 1983. Wings along the Winnipeg: the birds of the Pinawa - Lac du Bonnet region, Manitoba. Eco Series No. 2, Man. Nat. Soc., Winnipeg. pp 159-160.

7 TERRES, J.K. 1980. The Audubon Society Encyclopedia of North American birds. Alfred A. Knopf, New. York.

\section{CHRISTMAS BIRD AND MAMMAL COUNTS - 1988}

The count period is from 16 December 1988 to 3 January 1989, inclusive. Count area should be a circle $24 \mathrm{~km}$ (15 mi) in diameter and counts must be a minimum of 3 hours in duration. Count forms will be mailed to compilers of counts in 1987 . Anyone else wishing to do a count should request a form from:

\section{Wayne C. Harris}

Box 414

Raymore, Saskatchewan. S0A 3 J0

Reports of counts should sent to Wayne as soon as possible after the count. To be included in the compilation in the March Blue Jay the reports must reach Wayne by 10 January 1989 at the latest. 